\title{
HEALTH PROMOTION FAKTOR RISIKO SINDROM METABOLIK DI POSBINDU MARGAMULYA KECAMATAN SINGAPARNA TAHUN 2018
}

\section{OLEH :}

\author{
Wuri Ratna Hidayani, S.K.M., M.Sc \\ (wuri.ratnahidayani@yahoo.co.id)
}

\section{A. DASAR PEMIKIRAN}

Sindrom metabolik merupakan kelompok abnormalitas metabolik pada seorang individu yang dihubungkan dengan risiko yang meningkat dari penyakit kardiovaskuler (Soleha, et al, 2016). Sindrom metabolik adalah kumpulan gangguan metabolisme seperti obesitas sentral, hipertensi, intoleransi glukosa dan dislipidemia yang dapat menyebabkan terjadinya berbagai penyakit degeneratif seperti penyakit kardiovaskuler (PKV), stroke, diabetes melitus tipe 2 (Sihombing, et al, 2015). Berdasarkan hasil penelitian Hidayani (2017) pada penelitian kasus kontrol di Wilayah Kerja Puskesmas Singaparna menyatakan bahwa jenis kelamin pendidikan, pekerjaan, kebiasaan merokok, dan aktivitas fisik tidak berhubungan dengan sindrom metabolik $(\mathrm{p}>0,05)$. Ada hubungan antara umur $(\mathrm{OR}=3,33 ; p=0,0071)$ dan pola makan $(\mathrm{OR}=2,70 ; p=0,027)$ dengan sindrom metabolik pada orang dewasa di Wilayah Kerja Puskesmas Singaparna Tahun 2017. Hasil analisis regresi logistik diketahui pola makan merupakan faktor dominan sindrom metabolik (Hidayani, 2017). Berdasarkan hasil penelitian tersebut, penulis tertarik untuk melakukan pengabdian masyarakat "Health Promotion Faktor Risiko Sindrom Metabolik di Posbindu Margamulya Kecamatan Singaparna Tahun 2018

\section{B. TUJUAN}

\section{Tujuan Umum}

Melakukan upaya pencegahan dan penanggulangan sindrom metabolik dengan health promotion faktor risiko sindrom metabolik di Posbindu Margamulya Kecamatan Singaparna

\section{Tujuan Khusus}

a. Penyebarluasan informasi untuk meningkatkan pengetahuan sindrom metabolik kepada masyarakat tentang sindrom metabolik.

b. Memberikan informasi tentang faktor risiko dan perilaku berisiko sindrom metabolik. c. Kampanye kesehatan program berhenti merokok, pola makan sehat dan aktivitas fisik

d. Memberikan kesadaran pada masyarakat untuk berhenti merokok sebagai salah satu upaya pencegahan sindrom metabolik

e. Memberikan kesadaran kepada masyarakat untuk mengkonsumsi gizi seimbang, pola makan yang sehat sebagai upaya pencegahan sindrom metabolik

f. Memberikan kesadaran kepada masyarakat untuk melakukan aktivitas fisik seperti senam minimal 30 menit per hari sebagai upaya pencegahan sindrom metabolik. 


\section{SASARAN}

Masyarakat peserta Posbindu Margamulya

\section{WAKTU DAN TEMPAT PELAKSANAAN}

Hari/ Tanggal : Rabu, 19 Desember 2018

Pukul : 08.30-12.00 WIB

Tempat : Posbindu Margamulya

\section{E. HASIL KEGIATAN}

Bentuk Kegiatan pengabdian masyarakat ini antara lain :

Health Promotion :
a. Penyuluhan faktor risiko sindrom metabolik
b. Penyuluhan bahaya merokok
c. Penyuluhan pentingnya gizi seimbang pengaturan menu makan sehat sehari-hari
d. Penyuluhan pentingnya aktivitas fisik
e. Presentasi hasil penelitian ilmiah Sindrom metabolic

Dengan hasil sebagai berikut ini :

1. Peningkatan pemahaman dan pengetahuan tentang faktor-faktor risiko sindrom metabolik masyarakat Margamulya

2. Pengetahuan tentang faktor-faktor risiko sindrom metabolik warga Margamulya meningkat sehingga adanya kesadaran untuk merubah gaya hidup dalam upaya preventif sindrom metabolik.

3. Masyarakat Margamulya memberikan respon positif terbukti adanya tanya jawab tentang faktor risiko sindrom metabolik seperti perilaku merokok, pola makan dan aktivitas fisik.

4. Masyarakat bersemangat mengikuti penyuluhan dan diharapkan dapat menghindari faktor risiko sindrom metabolik, mengaplikasikan pola hidup sehat terutama kebiasaan pola makan dengan mengkonsumsi gizi seimbang, menghindari merokok, dan aktivitas fisik.

\section{F. DAFTAR PUSTAKA}

Hidayani, Wuri Ratna; Supriyani, Teni. Faktor-Faktor Risiko yang Berhubungan dengan Sindrom Metabolik pada Orang Dewasa di Wilayah Kerja Puskesmas Singaparna Kabupaten Tasikmalaya Tahun 2017. Prosiding Forum Ilmiah Tahunan (FIT) IV Lampung 17-18 Oktober, IAKMI, hal 110-119. 2017

Sihombing, Marice; Tjandrarini, Dwi Hapsari. Faktor Risiko Sindrom Metabolik pada Orang Dewasa di Kota Bogor (Risk Factor Metacbolic Syndrome Among Adult in Bogor). Penelitian Gizi dan Makanan, Juni 2015 Vol. 38 (1): 21 30. 2015.

Soleha, Tri Umiana; Bimandama, M. Azzaky. Hubungan Sindrom Metabolik dengan Penyakit Kardiovaskuler. Majority Volume 5,Nomor 2,April 2016 p.49-54 


\section{G. DOKUMENTASI}

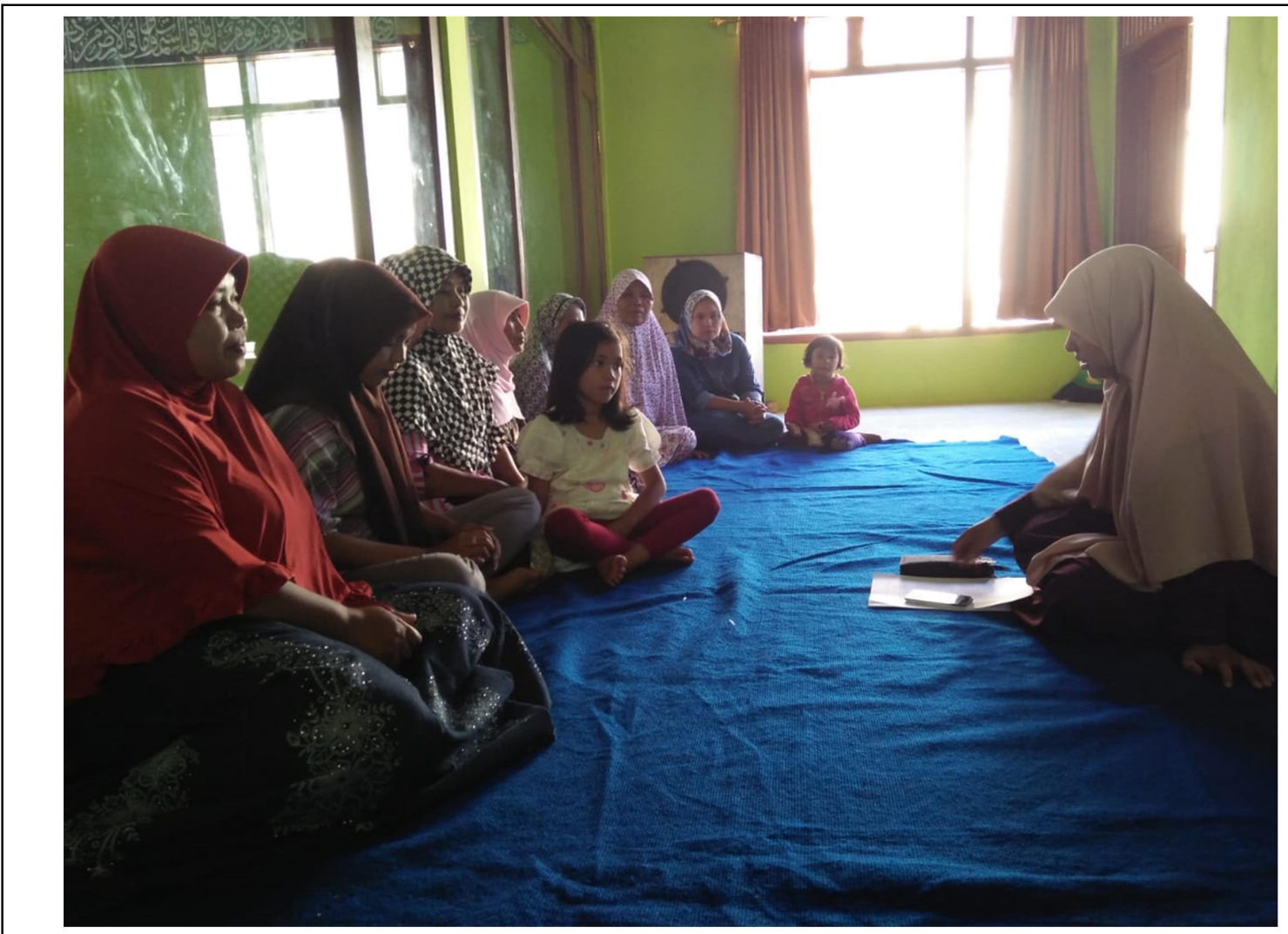

Health Promotion Sindrom Metabolik di Posbindu Margamulya 